\title{
RECENZIÓ A ZONGORAISKOLA 1. KEZDŐKNEK KÖTETRŐL
}

\section{A recenzió szerzője}

Réti Tamás (Drs)

Eszterházy Károly Egyetem

(Magyarország)

Szerző e-mail címe:

retitamas82@gmail.com

\section{Lektorok:}

Mészáros László (Ph.D.)

Károli Gáspár Református Egyetem

(Magyarország)

Eckhardt Gábor (DLA)

Liszt Ferenc Zenemúvészeti Egyetem

(Magyarország)

...és további két anonim lektor

Réti Tamás (2020): Recenzió a Zongoraiskola 1. kezdőknek kötetről. OxIPO - interdiszciplináris tudományos folyóirat, 2020/4, 103-105. doi: 10.35405/OXIPO.2020.4.103

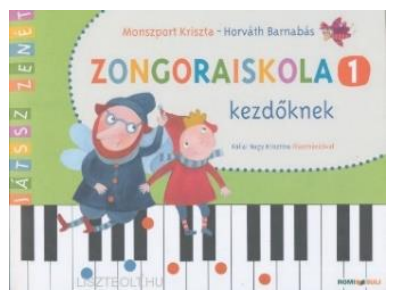

A recenzió alapjául szolgáló mủ bibliográfiája:

Monszport Kriszta és Horváth Barnabás (2018):

Zongoraiskola 1 kezdöknek. ROMI-SULI Könyvkiadó, Mogyoród. 64 oldal, ISMN 979-0-801670-45-8

Kulcsszavak: zongoraiskola, zenetanulás

Diszciplína: pedagógia

\section{Bibliography of the subject of this recension:}

Monszport Kriszta és Horváth Barnabás (2018): Pianoschool 1 for beginners. ROMISULI Könyvkiadó, Mogyoród. 64 oldal, ISMN 979-0-801670-45-8

Keywords: pianoschool, music learning

Discipline: pedagogy

A legkisebb korosztály számára pedagógiai céllal készült mű biztosítja a zongoratanulás során elsajátítandó alapvető elméleti és gyakorlati ismereteket. A kiad- vány az ismert magyar népdalkincs feldolgozásával juttatja el a tanulót a váltott kezes játéktól a két kezes játékig. A gyermekdalokhoz készült kísérettel illetve 
secondo szólamokkal lehetőséget teremt a kamaramuzsikálásra, ami biztosítja az együttzenélés örömét.

A Zongoraiskola 1 kezdőknek címú kiadvány 2018 szeptemberében jelent meg a ROMI-SULI Könyvkiadó gondozásában. A hangszeriskola szerzői a zenetanítás hazai gyakorló zenepedagógusai és oktatói. Monszport Kriszta a Nagykovácsi Alapfokú Művészeti Iskola zenetanára, valamint a Játssz Zenét módszer elindítója. Horváth Barnabás (DLA) 2013-ban Erkel Ferenc és 2017-ben KÓTA-díjjal kitüntetett zeneszerző, az LFZE zeneelméleti tanszékének oktatója. A kötetet Kállai Nagy Krisztina illusztrátor,- grafikus munkája színesíti.

A kiadvány elsődleges célja, hogy segítse a kezdők zenetanítását olyan módon, hogy az elméleti és a gyakorlatban elsajátítandó ismereteket az elemi magyar népdalkincsre alapozva kreatív módon dolgozza fel. Ennek következtében a mú szerzői széles körben ismert zenei anyag válogatásával segítik a gyakorló pedagógusokat, és adaptívan hozzájárulnak a hangszerjáték első lépéseinek megtételéhez.

A hazai alapfokú zeneoktatásban számos kiadvány létezik a kezdők zongoratanítása számára, azonban a jelen kiadvány értékét kiemelten növeli a gyermekek érdeklődését felkeltő belső és külső megjelenés, továbbá a társas zenélésre ösztönző zenei anyag.

A 64 oldalas, fekvő elhelyezkedésű kiadvány már a külső és belső áttanulmá- nyozása után a kotta fellapozására szólít fel. A belső borítón egy ábra a zenei abc törzshangjait összekapcsolja a zongorabillentyűkkel és a vonalrendszerrel szemléltetve az elmélet és a gyakorlat közötti hidat -, továbbá a zenei kifejezések tematikus csoportosításával ismertet meg.

A tizenegy fejezet hangszertechnikai feladatok szerint jól strukturált, ezzel összhangban didaktikailag felépített, a bennük foglalt zenei tartalom a zenét tanuló kisgyermekek érzelemvilágához közelálló, többnyire gyermekdalokat tartalmaz. Figyelemre méltó, hogy az első fejezetet megelőzve a szerzők, az alapvető hangszerjátékhoz (kéztartás, ujjrend, ülés, testtartás) és zeneelméleti ismeretekhez (kottaolvasás, lüktetés, ritmusértékek, vonalrendszer) is támpontot adnak a füzetet forgató tanulóknak.

Az első fejezet a váltott kezes tenuto játékmód elsajátítására épít hét gyermekdalon keresztül. Az egész hangjegyértékek megszólaltatásától fokozatosan jutunk el a nyolcad mozgásig. A zeneművek megszólaltatása igényli a karral történő hangindítást fogott ujjvégérzettel, ami a zongorázás mechanikájának kialakításánál fontos követelmény.

A kiadvány következő fejezete Amilcare Ponchielli: Órák tánca című múvét dolgozza fel négykezes formában. Ebben a zenemúben találkozik a kottát használó a staccato billentéssel.

A harmadik fejezet a kilenc zenei szemelvénnyel az ujjak finommotorikájára épít, 
s ennek következtében a legato billentés elsajátítására törekszik.

A gyermekek örömére a negyedik fejezet a Fecskét látok, és a Mackó, mackó, ugorjál gyermekdalokon keresztül a tükörjáték alkalmazásával egyszerre aktiválja a játszóapparátust.

A következő négy fejezetben az öt ujj fokozatos játéktérbe való bevonásával a tükör és váltott kezes játékmódokon keresztül jutunk az unisono játékhoz.

A kilencedik és tizedik fejezetek az eddig elsajátított ismereteket új ritmusképlettel, a szinkópával bővítik.

A kötet zárása tizenegy gyermekdalon keresztül a kétkezes játékig juttatja el a gyermeket.

A szerzők a kiadvány kialakításával törekedtek a 21. századi igények kielégítésére, ami a gazdag színvilágával azonnal elragadja a tanulót. Az oktatási céllal készült mű a legkisebb korosztály számára is biztosítja az ismeretek feldolgozását a tanulást támogató képek, illusztrációk és az útmutatást nyújtó ábráknak köszönhetően. A kiadvány erénye, hogy nem sietteti a zongorista növendéket, továbbá az elméleti és gyakorlati ismeretek kelló zenei anyagon keresztül vezetik el a játékost a váltott kezes billentéstôl az unisono játékon át a két kezes játékig.

Az eddigi gyakorlatban lévő kottákhoz képest a dalokhoz készült kísérettel illetve secondo szólamokkal felkelti a társas zenélés iránti vágyat, továbbá lehetőséget teremthet a családon belüli kamaramuzsikálásra. A gyermekdalok szövegének minden versszaka megjelenik, ezt gazdag illusztráció kíséri, ami a szöveg megértésére ad lehetőséget.

Összefoglalva a zongoraiskola kellő mennyiségú zenei anyaggal és a tanulást segítő ismerettel vértezi fel a legfiatalabb zongorázni vágyó korosztályt, ezért hozzájárul ahhoz, hogy elsajátítsák az első hangszertechnikai és elméleti ismereteket. A játékos módszerek, a gazdag képi anyag, valamint a gyermekdalokhoz készült kortárs zenei kíséret együttesen kelti fel az érdeklődést a zene világába való belépéshez. 